\author{
Research Article \\ www.ijrap.net
}

\title{
VALIDATED ZERO AND FIRST ORDER DERIVATIVE SPECTROPHOTOMETRIC METHODS FOR THE ESTIMATION OF POORLY SOLUBLE ANTIRETROVIRALS
}

\author{
Himaja Malipeddi*, Kalpana Jayapalu, Chaitra Muralidhara
}

Pharmaceutical Chemistry Division, SAS, VIT University, Vellore, Tamilnadu, India

Received on: 04/03/15 Revised on: 23/04/15 Accepted on: 02/05/15

\author{
*Corresponding author \\ Dr (Mrs). M. Himaja, Professor, Pharmaceutical Chemistry Division, SAS, VIT University, Vellore-632014. Tamil Nadu, India \\ Email:drmhimaja@gmail.com
}

DOI: $10.7897 / 2277-4343.06371$

\begin{abstract}
Two highly simple, sensitive and rapid derivative spectrophotometric methods were developed for the estimation of efavirenz and nevirapine in bulk and pharmaceutical dosage forms. The standard and sample solutions were prepared using methanol and distilled water in the ratio of 40:60 (azeotropic mixture). The spectrophotometric estimation of efavirenz and nevirapine was carried out using the using the zero order derivative values measured at 247 and $282 \mathrm{~nm}$ respectively and the first order derivative values measured at 257 and $299 \mathrm{~nm}$ respectively. Calibration graphs constructed at their wavelengths of determination were linear within the concentration range of $4-24 \mu \mathrm{g} / \mathrm{ml}$ for zero order and first order derivative spectrophotometric method. Both the proposed methods have been extensively validated as per ICH guidelines. No significant difference between the performance of the proposed methods regarding the mean values and standard deviations were noticed and is suitable for the routine quality control application of active drugs in pharmaceutical formulations.
\end{abstract}

Keywords: Efavirenz, Nevirapine, Zero order derivative spectrum, first order derivative spectrum, validation.

\section{INTRODUCTION}

Efavirenz is chemically (4S)-6-chloro-4-(2cyclopropylethynyl)-4-(trifluoromethyl)-1H-3, $\quad 1$ benzoxazin-2-one. It is practically insoluble in water. Efavirenz is an antiretroviral drug which belongs to a class of non-nucleoside reverse transcriptase inhibitor (NNRTI) and is used as part of highly active antiretroviral therapy (HAART) for the treatment of a human immunodeficiency virus (HIV) type-1. The drug is used in combination with other anti-retroviral agents for the treatment of HIV-1 infection in children and adults ${ }^{1-2}$. Nevirapine (NVP) is 11-cyclopropyl-4-methyl-5,11dihydro-6Hdipyrido[3,2-b:2',3'-e][1,4]diazepin-6-one.

Nevirapine belongs to a class of drugs known as NonNucleoside Reverse Transcriptase Inhibitors (NNRTIs) with activity against $\mathrm{HIV}-\mathrm{I}^{3}$. It is practically insoluble in water. Literature study reveals that very few analytical methods have been reported for the estimation of efavirenz and nevirapine in bulk or in pharmaceutical formulations ${ }^{4-11}$. Both the drugs selected for the study are practically insoluble in water. In the existing methods, the organic solvents used for the estimation were costly and not environment-friendly. So we applied concept of azeotropic mixture and combined an organic solvent (methanol) with water and developed simple and cost effective spectrophotometric methods ${ }^{12}$ for the estimation of nevirapine and efavirenz. These methods were successfully applied to pharmaceutical formulations and no interferences from tablet excipients were found. The proposed methods were found to be simple, sensitive, accurate, precise, rapid and economical for the routine quality control application of the active drugs in pharmaceutical formulations.

\section{MATERIALS AND METHODS}

Efavirenz and nevirapine standard were procured as gift samples from Strides Arcolab Ltd. Bangalore, Karnataka, India and was used without further purification. All chemicals and reagents used were of analytical grade. All stock solutions were prepared using double distilled water. Spectrophotometric measurements were performed using a Jasco V 670 UV/VIS/NIR diode array spectrophotometer (scan speed $400 \mathrm{~nm} / \mathrm{min}$ and wavelength interval $1 \mathrm{~nm})$, associated with Spectra manager software (Jasco, Japan).

\section{Method Development \\ Preparation of Standard and Sample Solutions}

Stock solution of $800 \mu \mathrm{g} / \mathrm{ml}$ of efavirenz and nevirapine was prepared in azeotropic mixture (Methanol: Water, 40:60 v/v), for zero order and first order derivative spectrophotometric analysis. The standard solutions were prepared by dilution of the stock solution with azeotropic mixture in a concentration range of $4,8,12,16,20$ and $24 \mu \mathrm{g} / \mathrm{ml}$ for zero order and first order derivative spectrophotometric measurements. Methanol: Water, 40:60 v/v was used as a blank solution.

\section{Assay Procedure}

A total of 20 tablets of efavirenz were accurately weighed and powdered. Powder equivalent to $10 \mathrm{mg}$ was 
accurately weighed and transferred to volumetric flask of $25 \mathrm{ml}$ capacity. $15 \mathrm{ml}$ of the mixture of methanol and water $(40: 60, \mathrm{v} / \mathrm{v})$ was transferred to volumetric flask and sonicated for $5 \mathrm{~min}$. The flask was shaken and volume was made up to the mark with the mixture of methanol and water $(40: 60, \mathrm{v} / \mathrm{v})$. The above solution was filtered through Whatman filter paper $(0.45 \mathrm{~mm})$. From this solution, $5 \mathrm{ml}$ was transferred to volumetric flask of $25 \mathrm{ml}$ capacity. The volume was made up to the mark to get a concentration $80 \mu \mathrm{g} / \mathrm{ml}$ (Solution A). From the solution A, $1.5 \mathrm{ml}$ was transferred to volumetric flask of $10 \mathrm{ml}$ capacity. The volume was made up to the mark with the mixture of methanol and water $(40: 60, \mathrm{v} / \mathrm{v})$ to give a solution containing $12 \mu \mathrm{g} / \mathrm{ml}$ for both zero order and first order derivative spectrophotometric methods. Same procedure has been used for the nevirapine assay.

\section{Method A: Zero Order Spectroscopic Method}

The solutions of efavirenz and nevirapine were scanned in the range from 200- $400 \mathrm{~nm}$, the maximum absorbance was observed at 247 and $282 \mathrm{~nm}$ respectively and were applied for further drug analysis. The active drugs followed the Beer's- Lamberts law in the concentration range of $4-24 \mu \mathrm{g} / \mathrm{ml}$.

\section{Method B: First Order Derivative Spectroscopic Method}

The standard drug solutions in the concentration range of 4-24 $\mu \mathrm{g} / \mathrm{ml}$ was scanned in the first order derivative spectra. The first order derivative spectra showed maxima at 257 and $299 \mathrm{~nm}$ for efavirenz and nevirapine respectively. The amplitude of absorbance was measured and was plotted against concentration to give calibration curve, and regression equation was calculated. The amplitude was linear in the concentration range of 4-24 $\mu \mathrm{g} / \mathrm{ml}$.

Table 1: Intra and Inter day precision results

\begin{tabular}{|c|c|c|c|c|c|c|c|c|}
\hline \multirow{3}{*}{ Parameters } & \multicolumn{4}{|c|}{ Intraday precision } & \multicolumn{4}{c|}{ Inter day precision } \\
\cline { 2 - 9 } & \multicolumn{2}{|c|}{ Efavirenz } & \multicolumn{2}{c|}{ Nevirapine } & \multicolumn{2}{c|}{ Efavirenz } & Nevirapine \\
\cline { 2 - 9 } & S.D & \%RSD & S.D & \%RSD & S.D & \%RD & S.D & \%RD \\
\hline Zero derivative & 0.051316 & 0.22 & 0.00197 & 0.68 & 0.040415 & 0.29 & 0.0079 & 2.72 \\
\hline First derivative & 0.001193 & 0.37 & 0.0001 & 0.94 & 0.001808 & 0.41 & 0.000208 & 1.93 \\
\hline
\end{tabular}

Table 2: Accuracy results

\begin{tabular}{|c|c|c|c|c|c|c|c|c|c|}
\hline \multicolumn{10}{|c|}{ Zero order derivative method } \\
\hline \multirow{2}{*}{$\begin{array}{c}\text { Accuracy } \\
\text { Level }\end{array}$} & \multicolumn{2}{|c|}{ Absorbance } & \multirow{2}{*}{$\begin{array}{c}\text { Amount } \\
\text { added(mg) }\end{array}$} & \multicolumn{2}{|c|}{ Amount found(mg) } & \multicolumn{2}{|c|}{ \% recovery } & \multicolumn{2}{|c|}{ Mean recovery } \\
\hline & Efavirenz & Nevirapine & & Efavirenz & Nevirapine & Efavirenz & Nevirapine & Efavirenz & Nevirapine \\
\hline $80 \%$ & 1.2746 & 0.2904 & 8 & 7.96 & 8.12 & 98.66 & 101.5 & \multirow[t]{3}{*}{99.09} & \multirow[t]{3}{*}{100.46} \\
\hline $100 \%$ & 1.3118 & 0.2936 & 10 & 9.92 & 9.93 & 99.55 & 99.3 & & \\
\hline $120 \%$ & 1.3677 & 0.2890 & 12 & 11.98 & 12.08 & 99.08 & 100.6 & & \\
\hline \multicolumn{10}{|c|}{ First order derivative method } \\
\hline $80 \%$ & 0.0858 & 0.0103 & 8 & 7.97 & 7.92 & 99.6 & 99.0 & \multirow[t]{3}{*}{99.62} & \multirow[t]{3}{*}{99.82} \\
\hline $100 \%$ & 0.1258 & 0.0107 & 10 & 9.97 & 10.14 & 99.7 & 101.4 & & \\
\hline $120 \%$ & 0.1901 & 0.0106 & 12 & 11.95 & 11.89 & 99.58 & 99.08 & & \\
\hline
\end{tabular}

Table 3: Assay results of active drugs in pharmaceutical formulation

\begin{tabular}{|c|c|c|c|}
\hline \multicolumn{5}{|c|}{ Efavirenz } \\
\hline Parameters & Amount of Tablet label claim & Drug content \% & \% RSD \\
\hline Zero order & $60 \mathrm{mg}$ & 99.80 & 0.197 \\
\hline First order & $60 \mathrm{mg}$ & 99.10 & 0.915 \\
\hline \multicolumn{7}{|c|}{ Nevirapine } \\
\hline Zero order & $200 \mathrm{mg}$ & 99.55 & 0.6 \\
\hline First order & $200 \mathrm{mg}$ & 99.46 & 0.5 \\
\hline
\end{tabular}

Table 4: Regression analysis data and summary of validation parameters for the proposed methods

\begin{tabular}{|c|c|c|c|c|}
\hline \multirow[t]{2}{*}{ Parameter } & \multicolumn{2}{|c|}{ Zero order } & \multicolumn{2}{|c|}{ First order } \\
\hline & Efavirenz & Nevirapine & Efavirenz & Nevirapine \\
\hline Absorption maxima & 247 & 282 & 257 & 299 \\
\hline Beer's-Lamberts range $(\mu \mathrm{g} / \mathrm{ml})$ & $4-24$ & $4-24$ & $4-24$ & $4-24$ \\
\hline Regression equation $\mathrm{y}=\mathrm{mx}+\mathrm{c}$ & $\mathrm{y}=0.0475 \mathrm{x}-0.0297$ & $y=0.0264 x-0.0198$ & $y=0.0253 x+0.0021$ & $\mathrm{y}=0.0008 \mathrm{x}-0.0006$ \\
\hline Slope(m) & 0.0475 & 0.0264 & 0.0253 & 0.0008 \\
\hline Intercept(c) & 0.0297 & -0.0198 & 0.0021 & -0.0006 \\
\hline Correlation coefficient (r2) & 0.9994 & 0.9905 & 0.9990 & 0.9939 \\
\hline Mean Recovery \% & 99.09 & 100.46 & 99.62 & 99.82 \\
\hline Precision (\% RSD) & 0.22 & 0.68 & 0.37 & 0.94 \\
\hline Intermediate precision & 0.29 & 2.72 & 0.41 & 1.93 \\
\hline LOD $(\mu \mathrm{g} / \mathrm{ml})$ & 0.1132 & 0.5238 & 0.2011 & 0.5214 \\
\hline LOQ $(\mu \mathrm{g} / \mathrm{ml})$ & 0.3442 & 1.5875 & 0.2989 & 1.5800 \\
\hline
\end{tabular}



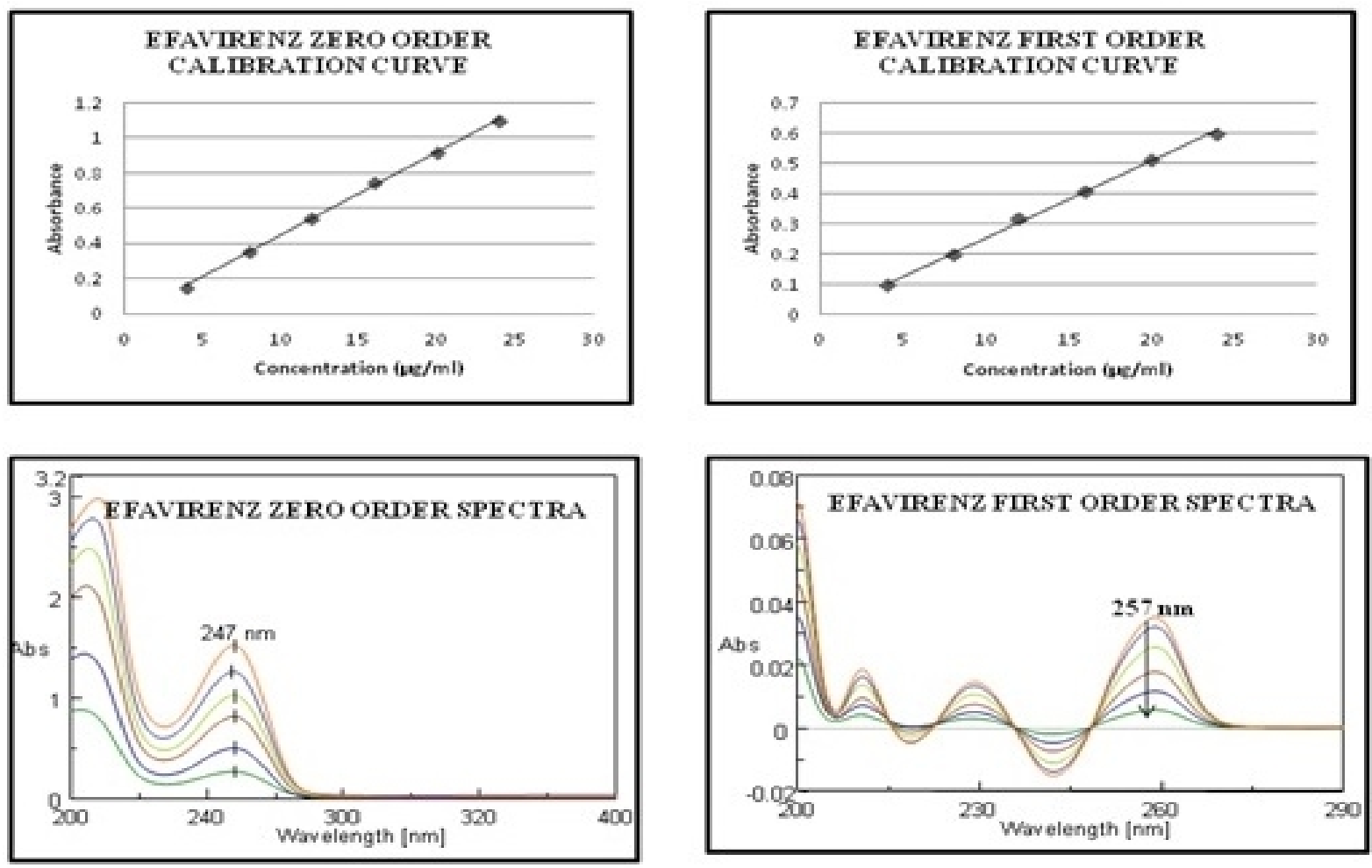

Figure 1: Efavirenz Calibration Curves
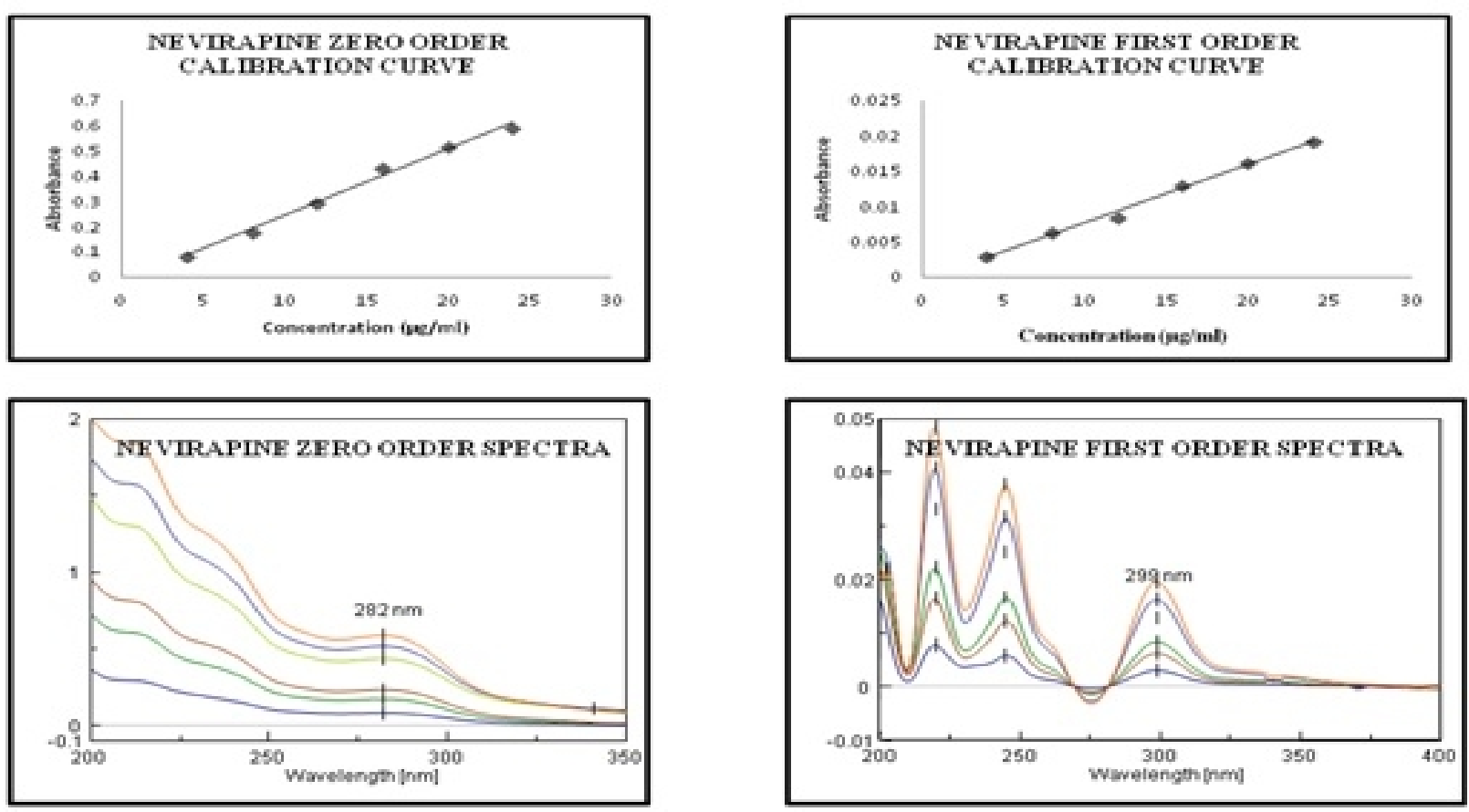

Figure 2: Nevirapine Calibration Curves 


\section{RESULTS AND DISCUSSION}

The developed method was validated for linearity, range, precision, accuracy, specificity, LOD and LOQ according to the International Conference on Harmonization (ICH) guidelines ${ }^{13}$. The zero order and first order derivative spectra were recorded at the wavelength of 247 and 257 for efavirenz, 282 and $299 \mathrm{~nm}$ for nevirapine respectively.

\section{Linearity and Range}

The calibration curves were obtained by plotting the absorbance against the drug concentration and were subjected to least square linear regression analysis to obtain the calibration equations and correlation coefficients. From stock solutions 4-24 $\mu \mathrm{g} / \mathrm{ml}$ concentration range solutions were prepared in azeotropic mixture. Under the experimental conditions described, the graph obtained for zero order and first order derivative spectra showed linear relationship for both the drugs. Regression analysis was made for the slope, intercept and correlation coefficient values. The regression equations of calibration curves of efavirenz and nevirapine were $\mathrm{y}=$ $0.0475 \mathrm{x}-0.0297\left(\mathrm{r}^{2}=0.9994\right)$ at $247 \mathrm{~nm}$ and $\mathrm{y}=0.0264 \mathrm{x}$ - $0.0198\left(\mathrm{r}^{2}=0.9905\right)$ at $282 \mathrm{~nm}$ respectively for zero order derivative spectrophotometry and $\mathrm{y}=0.0253 \mathrm{x}+$ $0.0021\left(\mathrm{r}^{2}=0.999\right)$ at $257 \mathrm{~nm}$ and $\mathrm{y}=0.0008 \mathrm{x}-0.0006\left(\mathrm{r}^{2}\right.$ $=0.9939)$ at $299 \mathrm{~nm}$ respectively for first order derivative spectrophotometry. The range was found to be $4-24 \mu \mathrm{g} / \mathrm{ml}$ for both zero order and first order derivative spectrophotometric methods. The calibration curves are showed in figures 1 and 2.

\section{Precision}

To determine the precision of the method, standard drug solutions at a concentration of $12 \mu \mathrm{g} / \mathrm{ml}$ were analyzed each five times for both zero order and first order derivative spectrophotometric methods. Solutions for the standard curves were prepared freshly. Measured the absorbance and calculated the \%RSD. The \%RSD for the five replicates absorbance was found to be within the specified limits. Solutions for the standards were freshly prepared at the time of analysis. The \% RSD for the area of five standard injections results should not be more than $2 \%$. The precision results are tabulated in table 1 .

\section{Sensitivity}

The limit of detection (LOD) and limit of quantification (LOQ) were calculated by using the equations LOD $=3 \sigma$ $/ \mathrm{S}$ and $\mathrm{LOQ}=10 \sigma / \mathrm{S}$, where $\sigma$ is the standard deviation of intercept, $\mathrm{S}$ is the slope. The LOD and LOQ results of efavirenz and nevirapine for zero order and first order derivative methods are tabulated in table 4 .

\section{Recovery}

Standard addition method was applied to study the accuracy of the proposed methods, and to check the interference from excipients used in the dosage. This study was performed by addition of known amounts of active drug to reanalyzed solutions of commercial tablets. Measured the absorbance of the standard solution, accuracy $80 \%$, accuracy $100 \%$ and accuracy $120 \%$ solutions and calculated the individual recovery and mean recovery values. The results are shown in table 2 .

\section{Analysis of the Marketed Formulation}

No interference from the excipients commonly present in the tablets was observed during the analysis. The drug content of efavirenz was found to be $99.8 \%$ with a $\%$ R.S.D. of 0.197 and $99.1 \%$ with a \% R.S.D. of 0.915 for zero order and first order derivative spectrophotometric methods respectively and the drug content of nevirapine was found to be $99.55 \%$ with a \% R.S.D. of 0.6 and $99.46 \%$ with a \% R.S.D. of 0.5 for zero order and first order derivative spectrophotometric methods respectively. It may therefore be inferred that degradation of efavirenz and nevirapine had not occurred in the marketed formulations that were analyzed by this method. The low $\%$ R.S.D. value indicated the suitability of this method for routine analysis of the active drugs in pharmaceutical dosage form. The results are shown in table 3 . The summary of the validation parameters is depicted in table 4.

\section{CONCLUSION}

Two spectrophotometric methods for quantifying efavirenz and nevirapine in bulk and formulation have been developed and validated as per ICH guidelines. The developed methods are selective, economically cheap and linear over the concentration range from $2 \mu \mathrm{g} / \mathrm{ml}$ to $24 \mu \mathrm{g} / \mathrm{ml}$ in the solvent of methanol and water (60:40). The developed methods can be concluded as accurate, sensitive and precise and can be easily applied for the routine quantification in pharmaceutical formulations.

\section{ACKNOWLEDGEMENT}

The authors are highly thankful to the Pharmaceutical Chemistry Division, School of Advanced Sciences, VIT University, Vellore, Tamil Nadu for providing facilities to carry out the work.

\section{REFERENCES}

1. Rang HP, Dale MM, Ritter JM. Pharmacology, 6th ed. Edinburg: Churchill Livingstone; 2007. http://dx.doi.org/10.1016/b978-0-44306911-6.50006-2

2. Rao BU, Nikalje AP. Stability- indicating HPLC method for the determination of efavirenz in bulk drug and in pharmaceutical dosage form. Afr J Pharm Pharmacol 2009; 3: 643-46.

3. Drug today medical journal. Lorina publication (India) Inc, Delhi91, 2012; 1: 578.

4. Sarkar M, Khandavilli S, Panchagnula R. Development and validation of RP-HPLC and ultraviolet spectrophotometric methods of analysis for the quantitative estimation of antiretroviral drugs in pharmaceutical dosage forms. J Chromatogr B 2006; 830 suppl 2: 349-54. http://dx.doi.org/10.1016/j.jchromb.2005.11.014

5. Anbazhagan S, Indumathy N, Shanmugapandiyan P, Sridhar SK. Simultaneous quantification of stavudine, lamivudine and nevirapine by UV spectroscopy, reverse phase HPLC and HPTLC in tablets. J Pharm Biomed Anal 2005; 39 suppl 3: 801-04. http://dx.doi.org/10.1016/j.jpba.2005.04.044

6. Bregt Kappelhoff S, Hilde Rosing, Alwin DR Huitema, Jos Beijnen H. Simple and rapid method for simultaneous determination of the non-nucleosidereverse transcriptase inhibitors efavirenz and nevirapine in human plasma using liquid chromatography. J 
Chromatogr B 2003; 792 suppl 2: 353-62. http://dx.doi.org/10.1016/S1570-0232(03)00325-8

7. Geetha Ramachandran AK, Hemanth Kumar, Soumya Swaminathan, Venkatesan P, Kumaraswami V and David Greenblatt J. Simple and rapid liquid chromatography method for determination of efavirenz in plasma. J Chromatogr B 2006; 835 suppl 1:131-35. http://dx.doi.org/10.1016/j.jchromb.2006.03.014

8. Agnes Veldkamp I, Rolf van Heeswijk PG, Pieter L, Meenhorst, Jan Mulder W, Joep MA et al. Quantitative determination of efavirenz (DMP266), a novel non-nucleoside reverse trancriptase inhibitor in human plasma using isocratic reversed-phase high performance liquid chromatography with ultraviolet detection. J Chromatogr B: Biomed Sci Appl 1999; 734 suppl 1: 55-61. http://dx.doi. org/10.1016/S0378-4347(99)00336-9

9. Matthews CZ, Woolf EJ, Mazenko RS, Haddix Wiener H, Chavez Eng CM, Constanzer ML et al. Determination of efavirenz, a selective non-nucleoside reverse transcriptase inhibitor, in human plasma using HPLC with post-column photochemical derivatization and fluorescence detection. J Pharm Biomed Anal 2002; 28 suppl 5: 925-34. http://dx.doi.org/10.1016/S0731-7085(01)00709-9

10. Lakshmi Sailaja, Kishore Kumar K, Ravi Kumar DVR, Mohan Kumar C, Yugandhar NM, Srinubabu G. Development and validation of a liquid chromatographic method for determination of efavirenz in human plasma. Chromatogr 2007: 65: 359-61. http://dx.doi.org/10.1365/s10337-006-0170-x

11. Cociglio M, Hillaire Buys-D, Peyriere H and Alric R. Performance analysis of a rapid HPLC determination with the solvent demixing extraction of HIV antiproteases and efavirenz in plasma. J Chromatogr Sci 2003: 41 suppl 2: 80-86. http://dx.doi.org/ 10.1093/chromsci/41.2.80

12. Choudary Pritam B, Pawar Pravin D and Narkedhe Kiran P. Stability indicating spectrophotometric method for the determination and validation of clopidogrel bisulphate in tablet dosage form. Int J Res Ayurveda Pharm 2010:2 (1): 418-23.

13. ICH, Text on validation of analytical procedures, International Conference on Harmonization, Geneva, 1994, 1-5.

\section{Cite this article as:}

Himaja Malipeddi, Kalpana Jayapalu, Chaitra Muralidhara. Validated zero and first order derivative spectrophotometric methods for the estimation of poorly soluble antiretrovirals. Int. J. Res. Ayurveda Pharm 2015;6(3):366-370 http://dx.doi.org/10.7897/2277-4343.06371 